\title{
Strongyloides IgG Antibody Measurement
}

National Cancer Institute

\section{Source}

National Cancer Institute. Strongyloides Ig G Antibody Measurement. NCI Thesaurus.

Code $C 117858$.

The determination of the amount of strongyloides Ig G antibody present in a sample. 